\title{
Prevalence and Determinants Factors that Influence the Behaviour of People with Pediculosis Capitis in Orphanage
}

\author{
Ahmad Ghiffari ${ }^{1, *}$,Anggun Nurul Fitria ${ }^{2}$,Chairil Anwar ${ }^{3}$, and Mutiara Budi Azhar ${ }^{4}$ \\ ${ }^{1}$ Department of Parasitology, Faculty of Medicine, Universitas Muhammadiyah Palembang, Indonesia \\ ${ }^{2}$ Students of Medical Faculty Universitas Sriwijaya, Palembang, Indonesia \\ ${ }^{3}$ Department of Parasitology, Faculty of Medicine, Universitas Sriwijaya, Palembang, Indonesia \\ ${ }^{4}$ Department of Anatomy, Faculty of Medicine, Universitas Sriwijaya, Palembang, Indonesia \\ chairi153@yahoo.co.id
}

\begin{abstract}
Pediculosis capitis infestation is caused by Pediculus humanus capitis louse. The prevalence of the disease is still quite high in Indonesia. This disease can cause a variety of problems, from reduced self-esteem, negative social stigma, lack of quality sleep and learning disorders. The study aimed to determine the prevalence and determinants factors that influence the behavior of people with pediculosis capitis in orphanage Kemuning. The cross-sectional design were sampled whole orphanages in the three subdistrict. The respondents were interviewed and examined with pediculosis using a lice comb and a magnifying glass. Later, parasites were storage into bottles containing $70 \%$ alcohol. Results showed the prevalence of pediculosis capitis $62 \%$ (36 respondents). The highest category was in the age $11-16$ years $(50.9 \%)$; female $(60 \%)$ and elementary education $(54.5 \%)$. Based on the illness practice $(100 \%)$ of the respondents had a bad illness behavior. There is no relationship of age, gender, education, and perception of illness behavior. Further research should proceed on best practice toward disease.
\end{abstract}

\section{Introduction}

Head lice infestation is a worldwide phenomenon that affects persons of all ages [1]. The human louse, Pediculus humanus, is an obligatory hematophagous parasite that thrived exclusively on human for around 5-7 million years ago [2][3]. Head lice (Pediculus humanus capitis) cause scalp irritation, social disruption, poor sleep, bacterial superinfection, and loss of school and caregiver work days [4]. Until recently, only the body louse acted as a vector for serious human disease [5]. Head lice infestations receive little medical attention or research funding [6]. They are often found in jails and in developing countries, nonetheless also re-emerging among homeless populations in developed countries [7].

There are hundreds of millions of cases of pediculosis worldwide [8]. Transmission is most commonly directly between individuals or indirectly by contact with linens, brushes,

\footnotetext{
*Corresponding author : chairil53@yahoo.co.id
} 
or clothes, according to the species [9]. Preliminary observations showed lack of environmental facilities and poor personal hygiene in the orphanage house. In the survey we intend to describe the knowledge-attitude- practice of the orphan with pediculosis capitis.

\section{Materials and Methods}

This is an observational analytic research with cross-sectional design to obtain the prevalence and the factors that influence the behaviour of pediculosis capitis in the Kemuning district, Palembang Indonesia. Population and sample study were located in three orphanages in Palembang.

Variables examined in this study were age, gender, education, knowledge and attitude toward parasites. Louse were stored in a bottle containing $70 \%$ alcohol, and labelled. Thus, prepared to be observed under a microscope in the parasitology laboratory of. Once the data is collected, the data is presented in the form of tables and figures.

\subsection{Measuring instruments}

Measuring instrument used in this study was a microscope and questionnaires. Respondents' hairs were examined, while questionnaires were used to obtain data on respondents' characteristic.

\subsection{Statistics Analysis}

The data obtained were analysed using SPSS program and displayed in tabular form. The relationship between the dependent variable and independent variables were determined by Chi-square test $(\alpha=0.05)$.

\section{Results and Discussions}

\subsection{Microscopic Examination}

Picture 1-2 showed the Pediculus humanus capitis, in form of adult male and female. The microscopic examination used the magnification of $10 \mathrm{X}$. Note that the male has a bigger claw, and spear in the genital part.

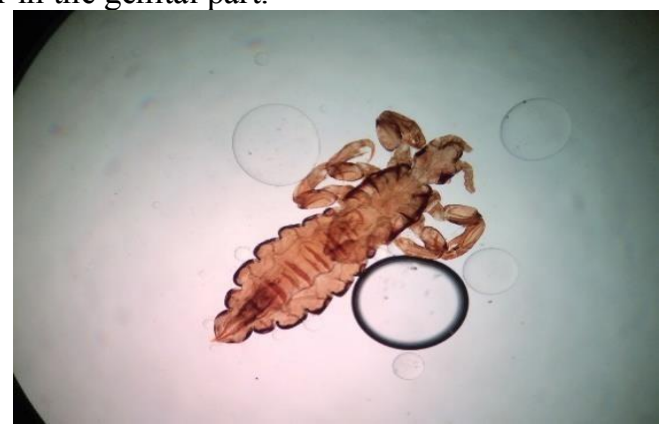

Fig. 1. Pediculus humanus capitis, adult male (10X). 


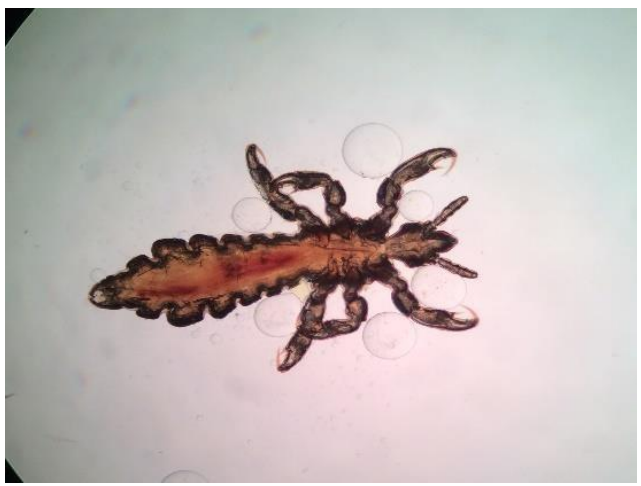

Fig. 2. Pediculus humanus capitis, adult female (10X).

\subsection{Questionnaire Analysis}

Table 1 showed the prevalence of the disease, which was as high as $62 \%$.

Table 1. Prevalence of pediculosis capitis $(\mathrm{N}=55)$.

\begin{tabular}{|c|c|c|}
\hline Pediculosis & N & \% \\
\hline Positive & 34 & 62 \\
\hline Negative & 21 & 38 \\
\hline Total & 55 & 100 \\
\hline
\end{tabular}

Table 2 showed the relation of age towards practice toward disease, which the dominant categories had a bad practice based on questionnaire.

Table 2. Relationship of age with the practice toward disease $(\mathrm{N}=55)$.

\begin{tabular}{|c|c|c|c|c|}
\hline \multirow{2}{*}{ Age } & \multicolumn{4}{|c|}{ Practice toward disease } \\
\cline { 2 - 5 } & \multicolumn{2}{|c|}{ Good } & \multicolumn{2}{|c|}{ Bad } \\
\cline { 2 - 5 } & $\mathbf{N}$ & $\mathbf{\%}$ & $\mathbf{N}$ & $\mathbf{\%}$ \\
\hline $5-10$ & 0 & 0 & 23 & 41.8 \\
\hline $11-16$ & 0 & 0 & 28 & 50.9 \\
\hline $17-23$ & 0 & 0 & 4 & 7.2 \\
\hline Total & 0 & 0 & 55 & 100.0 \\
\hline
\end{tabular}

Table 3 showed the relation of gender towards practice toward disease, which the dominant categories had a bad practice based on questionnaire.

Table 3. Relationship of gender with the practice toward disease $(\mathrm{N}=55)$.

\begin{tabular}{|c|c|c|c|c|}
\hline \multirow{2}{*}{ Gender } & \multicolumn{3}{|c|}{ Practice toward disease } \\
\cline { 2 - 5 } & \multicolumn{2}{|c|}{ Good } & \multicolumn{2}{|c|}{ Bad } \\
\cline { 2 - 5 } & $\mathbf{N}$ & $\mathbf{\%}$ & $\mathbf{N}$ & $\mathbf{\%}$ \\
\hline Male & 0 & 0 & 22 & 40 \\
\hline Female & 0 & 0 & 33 & 60 \\
\hline Total & 0 & 0 & 55 & 100 \\
\hline
\end{tabular}

Table 4 showed the relation of education towards practice toward disease, which the dominant categories had a bad practice based on questionnaire. 
Table 4. Relationship of education with the practice toward disease $(\mathrm{N}=55)$.

\begin{tabular}{|c|c|c|c|c|}
\hline & \multicolumn{4}{|c|}{ Practice toward disease } \\
\hline Education & \multicolumn{2}{|c|}{ Good } & \multicolumn{3}{|c|}{ Bad } \\
\hline & $\mathrm{n}$ & $\%$ & $\mathrm{n}$ & $\%$ \\
\hline Elementary school & 0 & 0 & 30 & 54.5 \\
\hline Junior high school & 0 & 0 & 19 & 34.5 \\
\hline Senior high School & 0 & 0 & 6 & 10.9 \\
\hline Total & 0 & 0 & 55 & 100 \\
\hline
\end{tabular}

Table 5 showed the relation of practice towards disease prevalence, which the dominant categories was the good category.

Table 5. Relation of perception with the prevalence $(\mathrm{N}=55)$

\begin{tabular}{|c|c|c|c|c|}
\hline \multirow{2}{*}{ Perception } & \multicolumn{4}{|c|}{ Practice toward disease } \\
\cline { 2 - 5 } & \multicolumn{2}{|c|}{ Good } & \multicolumn{2}{|c|}{ Bad } \\
\cline { 2 - 5 } & $\mathbf{N}$ & $\mathbf{\%}$ & $\mathbf{N}$ & $\mathbf{\%}$ \\
\hline Good & 0 & 0 & 30 & 54.5 \\
\hline Bad & 0 & 0 & 25 & 45.5 \\
\hline Total & 0 & 0 & 55 & 100 \\
\hline
\end{tabular}

Status of head lice as a vector of pathogens has been raised, since body louse-borne pathogens have been increasingly detected worldwide [10]. Our study represents an extremely high prevalence, $62 \%$, and dominant factors that affects the occurrence of pediculosis capitis.

Age remained a significant independent risk factor for the presence of scabies. Increased prevalence of head lice with age may be due to the greater chances of close contact $[11,12]$. Children aged 6-12 tend to gather in big groups are unaware of transmission mechanism [13]. After children, the elderly were the most affected [14]. They spend more time with children, attend nursing homes or similar collective environments.

The prevalence of P. h. capitis was high in girls [15]. The predominance of long-haired girls may provide a reservoir for the survival and reproduction of lice $[11,16]$. This can be explained by the difference of hair length and hair styles between sexes [13]. Girls play in small groups with more frequent head-to-head contact among each other, while boys prefer playing outside during sports or rough activities [17]. Conversely, Iranian boy students were more infested than those in most other countries [18].

Personal hygiene plays important role in development of pediculosis capitis [16]. Sharing common comb caused head lice infestation transmission by sharing infested instruments including hats, scarves, sweaters, sharing common pillows, etc [12]. Regular hair washing were the factors that accounted for both age and sex difference in prevalence of Pediculosis [17] [18]. Designated combs have been used for effective removal of adult lice or nymphs of $P$. h. capitis from the head [19]. With the exception of hair length, individual and household characteristics are of minor importance to predict head lice infestations in a low-prevalence country [20].

\section{Conclusion}

The prevalence of pediculosis capitis in orphanages was $60 \%$. The determinants characteristics were the majority of the age group 11-16 years, elementary education and, female gender. There is no relationship of prevalence with age, gender, education, and practice of illness. Further research should proceed on best practice toward disease. 


\section{Acknowledgments}

The authors greatly thank the Ministry of Research, Technology and Higher Education of the Republic of Indonesia for the grant. We are also grateful to the Head of Health Office Palembang of South Sumatra Province and the staffs who permitted allowing us to undertake research within the area.

\section{Reference}

1. Amanzougaghene N, Mumcuoglu K Y, Fenollar F, Alfi S, Yesilyurt G, Raoult D and Mediannikov $\mathrm{O}$ High ancient genetic diversity of human lice, pediculus humanus, from Israel reveals new insights into the origin of clade b lice PLoS One 11 (2019)

2. Reed D L, Smith V S, Hammond S L, Rogers A R and Clayton D H Genetic analysis of lice supports direct contact between modern and archaic humans PLoS Bio 2 (2004)

3. Light J E, Allen J M, Long L M, Carter T E, Barrow L, Suren G, Raoult D and Reed D LGeographic Distributions and Origins of Human Head Lice (Pediculus humanus capitis) Based on Mitochondrial Data J. Parasitol 94 (2008)

4. Koch E, Clark J M, Cohen B, Meinking T L, Ryan W G, Stevenson A, Yetman R and Yoon K S Management of Head Louse Infestations in the United States-A Literature Review Pediatr. Dermatol 33 (2016)

5. Candy K, Amanzougaghene N, Izri A, Brun S, Durand R, Louni M, Raoult D, Fenollar $\mathrm{F}$ and Mediannikov O Molecular Survey of Head and Body Lice, Pediculus humanus, in France. Vector-Borne Zoonotic Dis. 181 (2018)

6. Brouqui P. J. Rev. Entomol. 56 (2011)

7. Badiaga $\mathrm{S}$ and Brouqui $\mathrm{P}$ Human louse-transmitted infectious diseases Clin.Microbiol.Infect. 18 Chosidow O 2000 Scabies and pediculosis Lancet 355 (2012)

8. Chosidow O. Scabies and pediculosis Lancet 355 (2000)

9. AlBashtawy M and Hasna F Pediculosis capitis among primary-school children in Mafraq Governorate, Jordan. East. Mediterr. Heal. J. 18 (2012)

10. Amanzougaghene N, Fenollar F, Sangare A K, Sissoko M S, Doumbo O K, J PLoS One 12 (2017)

11. Gulgun M, Balci E, Karaoglu A, Cent. Eur. J. Public Health 21 (2013)

12. Vahabi A, Shemshad K, Sayyadi M, Biglarian A, Vahabi B, Sayyad S, Shemshad M and Rafinejad J Prevalence and risk factors of Pediculus (humanus) capitis (Anoplura: Pediculidae), in primary schools in Sanandaj city, Kurdistan province, Iran Trop. Biomed. 29 (2012)

13. Buczek A, Markowska-Gosik D, Widomska D and Kawa I M Pediculosis capitis among schoolchildren in urban and rural areas of eastern Poland Eur. J. Epidemiol. 19 (2004)

14. Nunes S C B, Moroni R B, Mendes J, Justiniano S C B and Moroni F T Head Lice in Hair Samples From Youths, Adults and the Elderly in Manaus, Amazonas State, Brazil.Rev.Inst. Med. Trop. Sao Paulo 57 (2015)

15. Karaaslan S and Yilmaz H The Distribution of Pediculus humanus capitis Among Primary School Pupils of the Turkish Chamber of Commerce and Stock Exchange Organisation in Van Turkish J. Parasitol. 39 (2015)

16. Ríos S M, Fernández J A, Rivas F, Sáonz M L and Moncada L I Prevalencia y factores 
asociados a la pediculosis en niños de un jardín infantil de Bogotá Biomedica 28 (2008)

17. Abd El Raheem T A, El Sherbiny N A, Elgameel A, El-Sayed G A, Moustafa N and Shahen S Epidemiological Comparative Study of Pediculosis Capitis Among Primary School Children in Fayoum and Minofiya Governorates, Egypt J. Community Health 40 (2015)

18. Moosazadeh M, Afshari M, Keianian H, Nezammahalleh A and Enayati A A Prevalence of Head Lice Infestation and Its Associated Factors among Primary School Students in Iran: A Systematic Review and Meta-analysis. Osong public Heal. Res. Perspect. 6 (2015)

19. Kurt Ö, Balcıŏlu I C, Limoncu M E, Girginkardeşler N, Arserim S K, Görgün S, Oyur T, Karakuş M, Düzyol D, Gökmen A A, Kitapçıŏlu G and Özbel Y.J. Parasitol. Res. 114 (2015)

20. Birkemoe T, Lindstedt H H, Ottesen P, Soleng A, Næss $\varnothing$ and Rukke B A. J. Pract. 33 (2016) 